\title{
Correction to: Gout In Extremis: Massive Soft Tissue Tophaceous Deposits
}

Melissa Rosas, MD and Paul Aronowitz, MD

Department of Internal Medicine, School of Medicine, University of California, Davis, Sacramento, CA, USA.

$\mathrm{J}$ Gen Intern Med

DOI: $10.1007 / \mathrm{s} 11606-019-05468-8$

(C) Society of General Internal Medicine 2019

C

\section{ORRECTION TO: J GEN INTERN MED \\ https://doi.org/10.1007/s11606- \\ 018-4662-9}

This paper was originally published with open access, but has since been granted retrospective open access cancellation.

Corresponding Author: Melissa Rosas, MD; Department of Internal Medicine, School of Medicine, University of California, Davis, Sacramento, CA, USA (e-mail: melrosas@ucdavis.edu).

Publisher's Note Springer Nature remains neutral with regard to jurisdictional claims in published maps and institutional affiliations.

The online version of the original article can be found at https://doi.org/10. 1007/s11606-018-4662-9 